\title{
PELATIHAN TEORI BELAJAR ORANG DEWASA BAGI PENDIDIK LEMBAGA PELATIHAN KETERAMPILAN (LPK) DI KOTA MANADO
}

\author{
Julduz R. Paus \\ Prodi Pendidikan Luar Sekolah, Fakultas Ilmu Pendidikan, UNIMA \\ udumdo@yahoo.co.id
}

\begin{abstract}
Luaran Perguruan Tinggi semakin "terasing" dengan kebutuhan dunia kerja yang ditandai dengan banyaknya sarjana sebagai pencari kerja bukan sebagai pencipta kerja. Lembaga Pendidikan dan Keterampilan (LPK) sebagai suatu solusi, karena dalam lembaga pendidikan nonformal tersebut warga belajar atau peserta didik diberi pengetahuan, sikap dan utamanya keterampilan. Karenanya, luaran LPK tidak hanya tahu, mau tetapi juga mampu (terampilan) melakukan sesuatu. Masalahnya adalah para pendidik LPK belum menguasai pengetahuan teoritis bagaimana seharusnya melaksanakan pembelajaran bagi orang dewasa. Untuk memecahkan masalah tersebut dilakukan pelatihan dilaksanakan pada bulan Mei 2016, selama 2 (dua) hari sabtu yaitu pada tanggal 7 dan 14 Mei 2016. dimulai pukul 10.00 pagi sampai dengan pukul 17.00 Wita. Tujuan pelatihan agar peserta memiliki pengetahuan tentang: (1) Sejarah dan Teori Belajar Orang Dewasa, (2) AsumsiAsusmsi belajar orang dewasa dan (3) Penerapan teori belajar orang dewasa dalam proses pembelajaran. Tujuan pelatihan tersebut sekaligus menjadi materi pembelajaran pelatihan. Tahapan pelatihan yaitu:(1) Perencanaan, (2) Pelaksanaan dan (3) Evaluasi. Melalui pelatihan tersebut warga belajar berhasil menguasai: (1) pengetahuan tentang Sejarah Teori Belajar Orang Dewasa, (2) asumsi-asumsi yang digunakan pada belajar orang dewasa dan (3) kemampuan dan kemauan untuk menerapkan teori teori pembelajaran orang dewasa dalam proses belajar and berlatih di LPK.
\end{abstract}

Keywords: Belajar orang dewasa, Lembaga Pendidikan dan Keterampilan.

\section{PENDAHULUAN}

Mencermati peran pendidikan saat ini maka dapat dikemukakan bahwa, pendidikan makin terisolasi dari kehidupan nyata ditandai dengan tamatan ragam lembaga pendidikan khususnya jenjang pendidkan tinggi dianggap kurang siap menghadapi kehidupan nyata atau komptensi yang dimiliki para sarjana tersebut tidak sesuai dengan komptensi yang diharapkan oleh lapangan pekerjaan. Suatu pendidikan dikatakan relevan dengan kehidupan nyata jika pendidikan tersebut sesuai dengan kebutuhan kehidupan nyata. Namun, pertanyaannya adalah kehidupan nyata yang mana? Sementara itu, kehidupan nyata sangat luas dimensi dan ragamnya, misalnya ada kehidupan pribadi, kehidupan keluarga, kehidupan masyarakat, dan kehidupan bangsa.

Sepatutnya, pendidikan harus relevan dengan berbagai kehidupan nyata itu. Namun, pada akhirnya perlu diambil keputusan mengenai manakah diantara kehidupan yang akan menjadi prioritas pada suatu kurun waktu tertentu. Dalam kerangka itu, terdapat empat strategi dasar kebijakan pendidikan, Lembaga Pendidikan dan Keterampilan (LPK) memiliki posisi strategis untuk menyiapkan tenaga kerja siap kerja atau siap berusaha. Sungguhpun patut diakui bahwa, masyarakat kita umumnya belum memandang LPK sebagai pilihan utama untuk meraih masa depan yang lebih baik bagi anak-anaknya. LPK dipandang sebagai lembaga pendidikan 
sampingan saja untuk mendukung pendidikan formal.

Pendidikan luar sekolah (PLS) bersama-sama dengan Pendidikan Sekolah (PS) diselenggarakan untuk meningkatkan kualitas daya pikir, daya kalbu dan daya fisik peserta didik sehingga yang bersangkutan memiliki lebih banyak pilihan dalam kehidupan, baik pilihan kesempatan untuk melanjutkan pndidikan yang lebih tinggi, pilihan kesempatan untuk bekerja maupun pilihan untuk mengembangkan dirinya. Untuk menecapai tujuan tersebut, PLS khususnya perlu memberikan bekal dasar kemampuan kesanggupan dan ketrampilan kepada peserta didik atau warga belajar agar mereka siap menghadapi berbagai kehidupan nyata. Telah banyak upaya yang dilakukan dalam memberikan bekal dasar kecakapan hidup, baik melalui pendidikan di keluarga, di sekolah, maupun di masyarakat. Upaya-upaya tersebut bukan tidak berhasil sama sekali dalam meningkatkan kemampuan, kesanggupan dan keterampilan hidup tamatannya, akan tetapi kehidupan nyata yang memiliki ciri "berubah" telah menuntut PLS untuk melakukan penyesuaian-penyesuaian PLS dituntut menghasilkan tamatanya yang mampu, sanggup, dan terampil untuk menghadapi tantangan hidup yang sarat kompetisi dan kolaborasi sekaligus. Mampu dalam arti tamatan PLS memiliki kualifikasi yang dibutuhkan bagi kehidupan masa depan. Sanggup dalam arti tamatan PLS mau, komit, bertanggung jawab dan 84 berdedikasi menjalankan kehidupannya. Terampil dalam arti cepat, cekat, dan tepat dalam mencapai sasaran hidup yang diinginkannya. Mengingat warga belajar PLS berada dalam kehidupan nyata, maka salah satu upaya yang perlu dilakukan adalah mendekatkan pendidikan (kegiatan belajar mengajar) dengan kehidupan nyata yang memiliki nilai-nilai preservative dan progresif sekaligus melalui pengintensi fan dan pengefektifan pendidikan kecakapan hidup.

Patut kita akui bahwa, Lembaga Pendidikan dan Keterampilan (LPK) adalah "pos terdepan dalam melayani kebutuhan belajar masyarakat yang tidak berkesempatan atau tidak mampu mengikuti pembelajaran pada jalur pendidikan formal. LPK juga memiliki peran stategis untuk menyiapkan tenaga kerja siap kerja. Persaingan dan tuntutan mutu tenaga kerja pada era Masyarakat Ekonomi Asis Tenggara (MEA) turut dipengaruhi oleh sejauhmana proses alih pengetahuan, sikap dan terutama keterampilan dari para pendidik di LPK kepada warga belajar yang umumnya orang dewasa.

Posisi orang dewasa sebagai warga belajar, memiliki karaktersitik yang berbeda dengan anak-anak sebagai peserta didik. Posisi orang dewasa sebagai warga belajar menuntut kemampuan khusus setiap pendidik agar proses pembelajaran mencapai tujuan yang dikehendaki. Disinilah terletak dilema itu. Disatu pihak para pendidik dituntut untuk 
mentraformasikan pengetahuan, sikap dan keterampilannya kepada warga belajar, sementera dalam kondisi yang bersamaan mereka belum memiliki pengetahuan teoritis tentang bagaimana sebenarnya orang dewasa itu belajar.

Konsep Andragogi didasarkan pada sedikitnya 4 asumsi tentang karakteristik warga belajar yang berbeda dari asumsi yang mendasari pedagogi tradisional,yaitu: 1) konsep diri mereka bergerak dari seseorang dengan pribadi yang tergantung kepada orang lain kearah seseorang yang mampu mengarahkan diri sendiri. 2) Mereka telah mengumpulkan segudang pengalaman yang selau bertambah yang menjadi sumber belajar yang semakin kaya.

3) Kesiapan belajar mereka menjadi semakin berorientasi kepada tugas-tugas perkembangan dari peranan sosial mereka.

4) Perspektif waktu mereka berubah dari penerapan yang tidak seketika dari pengetahuan yang mereka peroleh kepada penerapan yang segera, dan sesuai dengan itu orientasi mereka kearah belajar bergeser dari yang berpusat kepada mata pelajaran kepada yang berpusat kepada penampilan. Usaha-usaha ke arah penerapan teori andragogi dalam kegiatan pendidikan orang dewasa telah dicobakan oleh beberapa ahli, berdasarkan empat asumsi dasar orang dewasa yang di atas yaitu: konsep diri, akumulasi pengalaman, kesiapan belajar, dan orientasi belajar. Asumsi dasar tersebut dijabarkan dalam proses perencanaan kegiatan pembelajaran dengan langkah-langkah sebagai berikut: a. Menyiapkan Iklim Belajar yang Kondusif. Faktor lingkungan berpengaruh terhadap keberhasilan belajar. Oleh karena itu, dalam pembelajaran model Andragogi langkah pertama yang harus dikerjakan adalah menyiapkan iklim belajar yang kondusif. Ada tiga hal yang perlu disiapkan agar tercipta iklim belajar yang kondusif itu. Pertama, penataan fisik seperti ruangan yang nyaman, udara yang segar, cahaya yang cukup, dan sebagainya. Termasuk di sini adalah kemudahan memperoleh sumber-sumber belajar baik yang bersifat materi seperti buku maupun yang bukan bersifat materi seperti bertemu dengan fasilitator. Kedua, penataan iklim yang bersifat hubungan manusia dan psikologis seperti terciptanya suasana atau rasa aman, saling menghargai, dan saling bekerjasama. Ketiga, penataan iklim organisasional yang dapat dicapai melalui kebijakan pengembangan SDM, penerapan filosofi manajemen, penataan struktur organisasi, kebijakan finansial, dan pemberian insentif. b. Menciptakan Mekanisme Perencanaan Bersama. Perencanaan pembelajaran dalam model Andragogi dilakukan bersama antara fasilitator dan peserta didik. Dasarnya ialah bahwa peserta didik akan merasa lebih terikat terhadap keputusan dan kegiatan bersama apabila peserta didik terlibat dan berpartisipasi dalam perencanaan dan pengambilan keputusan. c. Menetapkan Kebutuhan Belajar. Dalam proses pembelajaran orang dewasa perlu diketahui 
lebih dahulu kebutuhan belajarnya. Ada dua cara untuk mengetahui kebutuhan belajar ini adalah dengan model kompetensi dan model diskrepensi. Model kompetensi dapat dilakukan dengan mengunakan berbagai cara seperti penyusunan model peran yang dibuat oleh para ahli. Pada tingkat organisasi dapat dilakukan dengan melaksanakan analisis sistem, analisis performan, dan analisis berbagai dokumen seperti deskripsi tugas, laporan pekerjaan, penilaian pekerjaan, analisis biaya, dan lainlain. Pada tingkat masyarakat dapat digunakan berbagai informasi yang berasal dari penelitian para ahli, laporan statistik, jurnal, bahkan buku, dan monografi. Model dikrepensi, adalah mencari kesenjangan. Kesenjangan antara kompetensi yang dimodelkan dengan kompetensi yang dimiliki oleh peseta didk. Peseta didik perlu melakukan self assesment. d. Merumuskan Tujuan Khusus (Objectives) Program Tujuan pembelajaran ini akan menjadi pedoman bagi kegiatan-kegiatan pengalaman pembelajaran yang akan dilakukan. Banyak terjadi kontroversi dalam merumuskan tujuan pembelajaran ini karena perbedaan teori atau dasar psikologi yang melandasinya. Pada model Andragogi lebih dipentingkan terjadinya proses selfdiagnosed needs. e. Merancang Pola Pengalaman Belajar Untuk mencapai tujuan yang telah ditetapkan perlu disusun pola pengalaman belajarnya atau rancangan programnya. Dalam konsep Andragogi, rancangan program meliputi pemilihan 86 problem areas yang telah diidentifikasi oleh peserta didik melalui self-diagnostic, pemilihan format belajar (individual, kelompok, atau massa) yang sesuai, merancang unit-unit pengalaman belajar dengan metoda-metoda dan materi-materi, serta mengurutkannya dalam urutan yang sesuai dengan kesiapan belajar peserta didik dan prinsip estetika. Rancangan program dengan menggunakan model pembelajaran Andargogi pada dasarnya harus dilandasi oleh konsep self-directed learning dan oleh karena itu rancangan program tidak lain adalah preparat tentang learning-how-to-learn activity. $\mathrm{f}$. Melaksanakan Program (Melaksanakan Kegiatan Belajar). Catatan penting pertama untuk melaksanakan program kegiatan belajar adalah apakah cukup tersedia sumberdaya manusia yang memiliki kemampuan membelajarkan dengan menggunakan model Andragogi. Proses pembelajaran Andragogi adalah proses pengembangan sumberdaya manusia. Peranan yang harus dikembangkan dalam pengembangan sumberdaya manusia adalah peranaan sebagai administrator program, sebagai pengembang personel yang mengembangkan sumberdaya manusia. Dalam konteksi pelaksanaan program kegiatan belajar perlu dipahami hal-hal yang berkaitan dengan berbagai teknik untuk membantu orang dewasa belajar dan yang berkaitan dengan berbagai bahan-bahan dan alat-alat pembelajaran. g. Mengevaluasi Hasil Belajar dan Menetapkan 
Ulang Kebutuhan Belajar Proses pembelajaran model Andragogi diakhiri dengan langkah mengevaluasi program. Pekerjaan mengevaluasi merupakan pekerjaan yang harus terjadi dan dilaksanakan dalam setiap proses pembelajaran. Tidak ada proses pembelajaran tanpa evaluasi. Proses evaluasi dalam model pembelajaran Andragogi bermakna pula sebagai proses untuk merediagnosis kebutuhan belajar. Untuk membantu peserta didik mengenali ulang model-model kompetensi yang diharapkannya dan mengasses kembali diskrepensi antara model dan tingkat kompetensi yang baru dikembangkannya. Pengulangan langkah diagnosis menjadi bagian integral dari langkah evaluasi. Dalam khasanah proses evaluasi terdapat empat langkah yang diperlukan untuk mengefektifkan assessment program yaitu evaluasi reaksi yang dilaksanakan untuk mengetahui bagaimana peserta didik merespon suatu program belajar; evaluasi belajar dilaksanakan untuk mengetahui prinsip-prinsip, fakta, dan teknik-teknik yang telah diperoleh oleh peserta didik; evaluasi perilaku dilaksanakan untuk memperoleh informasi perubahan perilaku peserta didik setelah memperoleh latihan; dan evaluasi hasil dilaksanakan untuk mengetahui tingkat keberhasilan program. Aplikasi yang diutarakan di atas sebenarnya lebih bersifat prinsip-prinsip atau ramburambu sebagai kendali tindakan membelajarkan orang dewasa. Oleh karena itu, keberhasilannya akan lebih benyak tergantung pada setiap pelaksanaan dan tentunya juga tergantung kondisi yang dihadapi. Jadi, implikasi pengembangan teknologi atau pendekatan andragogi dapat dikaitkan terhadap penyusunan kurikulum atau cara mengajar terhadap warga belajar. Namun, karena keterikatan pada sistem lembaga yang biasanya berlangsung, maka penyusunan program atau kurikulum dengan menggunakan andragogi akan banyak lebih dikembangkan dengan menggunakan pendekatan ini. Sebagai orang dewasa merasakan bahwa konsepdiri seseorang dapat berubah. Mereka mulai melihat peranan sosial mereka dalan hidup tidak lagi sebagai warga belajar "full time". Mereka melihat diri mereka semakin sebagai penghasil atau pelaku. Sumber utama kepuasan-diri mereka sekarang adalah penampilan mereka sebagai pekerja, suami/isteri, orang tua, dan warga negara. Orang dewasa memperoleh status baru, di mata mereka dan orang-orang lain, dari tanggung jawab yang non-pendidikan ini. Konsep-diri mereka menjadi sebagai pribadi yang mengarahkan dirinya sendiri. Mereka melihat diri mereka sendiri sebagai mampu membuat keputusan-keputusan mereka sendiri dan menghadapi akibatakibatnya, mengelola hidup mereka sendiri. Dalam hal itu mereka juga mengembangkan satu kebutuhan psikologis yang dalam untuk dilihat orang lain sebagai orang yang mampu mengarahkan diri sendiri. Orang dewasa menemukan bahwa mereka dapat 
bertanggung jawab bagi pembelajaran mereka sendiri, sebagaimana mereka lakukan bagi segi-segi lain kehidupan mereka, mereka mengalami perasaan lega dan gembira. Kemudian mereka akan memasuki kegiatan belajar dengan keterlibatan-diri yang mendalam, dengan hasil yang seringkali mengejutkan bagi mereka sendiri dan para fasilitator mereka.

Penguasaan teoritis dan kemampuan aplikatif teori pembelajaran orang dewasa dalam proses pembelajaran pada satuan pendidikan nonformal termasuk LPK, menjadi suatu kebutuhan mendesak untuk segera diketahui oleh siapa saja yang mengabdi sebagai pendidik pada satuan pendidikan nonformal. Apapunn alasannya, profesi pendidik pasti berhubungan dengan pengembangan sumber daya manusia. Pengembangan sumber daya manusia membutuhkan keahlian khusus termasuk penguasaan teori bagaimana belajar orang dewasa.

Teori Belajar Adragogi dapat diterapkan apabila diyakini bahwa peserta didik (siswa-mahasiswa-peserta) adalah pribadi-pribadi yang matang, dapat mengarahkan diri mereka sendiri, mengerti diri sendiri, dapat mengambil keputusan untuk sesuatu yang menyangkut dirinya. Andragogi tidak akan mungkin berkembang apabila meninggalkan ideal dasar orang dewasa sebagai pribadi yang mengarahkan diri sendiri. Yang menjadi tolok ukur sebuah kedewasaan bukanlah umur, namun sikap dan perilaku, sebab tidak jarang orang yang 88 sudah berumur, namun belum dewasa. Memang, menjadi tua adalah suatu keharusan dan menjadi dewasa adalah sebuah pilihan yang tidak setiap individu memilihnya seiring dengan semakin lanjut usianya.

Dalam kegiatan pembelajaran, pendidik dituntut memiliki kemampuan memilih pendekatan pembelajaran yang tepat. Kemampuan tersebut sebagai sarana serta usaha dalam memilih dan menentukan pendekatan pembelajaran untuk menyajikan materi pembelajaran yang tepat dan sesuai dengan program pembelajaran. Untuk menentukan atau memilih pendekatan pembelajaran, hendaknya berangkat dari perumusan tujuan yang jelas. Setelah tujuan pembelajaran ditentukan, kemudian memilih pendekatan pembelajaran yang dipandang efisien dan efektif. Pemilihan pendekatan pembelajaran ini hendaknya memenuhi kriteria efisien dan efektif. Suatu pendekatan pembelajaran dikatakan efektif dan efisien apabila startegi tersebut dapat mencapai tujuan dengan waktu yang lebih singkat dari pendekatan yang lain. Kriteria lain yang perlu diperhatikan dalam memilih pendekatan pembelajaran adalah tingkat keterlibatan peserta didik dalam proses pembelajaran. Strategi pembelajaran merupakan kegiatan yang dipilih pendidik dalam proses pembelajaran yang dapat memberikan kemudahan atau fasilitas kepada peserta didik menuju tercapainya tujuan yang telah ditetapkan. Strategi pembelajaran terdiri 
atas dua kata, strategi dan pembelajaran. Istilah strategi (strategy) berasal dari kata kerja dalam bahasa Yunani , "stratego" yang berarti merencanakan (to plan). Strategi adalah suatu pola yang direncanakan dan ditetapkan secara sengaja untuk melakukan kegiatan atau tindakan. Strategi mencakup tujuan kegiatan yang terlibat dalam kegiatan, isi kegiatan, proses kegiatan dan sarana penunjang kegiatan. Strategi yang diterapkan dalam kegiatan pembelajaran disebut strategi pembelajaran. Pembelajaran adalah upaya sistematis dalam membantu warga belajar dalam mengembangkan potensinya secara optimal melalui kegiatan belajar. Strategi pembelajaran mencakup penggunaan pendekatan, metode dan teknik, bentuk media, sumber belajar, peserta didik, untuk mewujudkan interaksi edukasi antara pendidik dengan peserta didik dengan lingkungannya.

Tujuan strategi pembelajaran adalah untuk mewujudkan efisiensi, efektivutas dan produktifitas kegiatan pembelajaran. Isi kegiatan pembelajaran adalah bahan/materi pembelajaran yang bersumber dari kurikulum yang telah disusun dalam program pembelajaran. Proses kegiatan pembelajaran merupakan langkah-langkah atau tahapan yang harus dilalui oleh pendidik dan peserta didik dalam pembelajaran. Sumber pendukung kegiatan pembelajaran mencakup fasilitas dan alat-alat bantu pembelajaran (Sudjana, 2005) Menurut Dick dan Carey (1990 : 1) strategi pembelajaran adalah suatu pendekatan dalam mengelola secara sistematis kegiatan pembelajaran sehingga warga belajar dapat mencapai isi pelajaran atau mencapai tujuan seperti yang diharapkan. Lebih lanjut Dick dan Carey (1990: 1) menyebutkan lima komponen umum dari strategi instruksional sebagai berikut: 1) kegiatan pra instruksional, 2) penyajian informasi, 3) partisipasi peserta didik, 4) tes, dan 5) tindak lanjut. Gagne dan Briggs dalam Atwi Suparman (1996: 156) mengemukakan sembilan urutan kegiatan instruksional, yaitu: 1) memberikan motivasi atau menarik perhatian, 2) menjelaskan tujuan instruksional kepada peserta didik, 3) mengingatkan kompetensi prasyarat, 4) memberi stimulus (masalah, topik, dan konsep), 5) memberikan petunjuk belajar, 6) menentukkan penampilan peserta didik, 7) memberi umpan balik, 8) menilai penampilan, 9) menyimpulkan. Strategi pembelajaran orang dewasa pada pendidikan keaksaraan fungsional terdiri dari lima langkah kegiatan, yaitu menulis, membaca, berhitung, diskusi dan aksi/penerapan. Langkah-langkah tersebut, bukan berarti langkah yang baku/kaku atau harus berurutan. Tetapi bisa saja dilakukan secara acak, misalnya dimulai dari diskusi, kemudian belajar membaca, menulis dan seterusnya. Hal ini tergantung dari situasi dan kondisi serta kesepakatan di dalam kelompok belajar. Namun demikian, kebiasaan yang ditemui adalah melalui 
diskusi terlebih dahulu baru dilanjutkan dengan kegiatan-kegiatan yang lain. Bisa juga dimulai dari masalah yang ditemui (aksi) peserta didik, kemudian didiskusikan di kelompok belajar, menulis, membaca dan seterusnya. Keefektifan kegiatan belajar, sangat bergantung pada kemampuan tutor dalam mengarahkan, dan membimbing peserta didik di dalam kegiatan belajarnya. Pengalaman juga menunjukkan bahwa, kegiatan menulis perlu didahulukan dan pada kegiatan membaca. Karena melalui kegiatan belajar menulis, peserta didik sedikit demi sedikit langsung belajar membaca. Sebaliknya apabila peserta didik didahulukan belajar membaca, maka cenderung kurang terampil dalam hal menulis. Kegiatan pembelajaran partisipatif sebagai upaya pembelajaran yang mengikutsertakan peserta didik dalam kegiatan pembelajaran. Menurut Sudjana (2005:155) keikutsertaan peserta didik diwujudkan dalam tiga tahapan kegiatan pembelajaran, yaitu: perencanaan program pembelajaran, pelaksanaan pembelajaran, dan penilaian pembelajaran. Partisipasi dalam perencanaan merupakan bentuk keterlibatan peserta didik dalam kegiatan mengidentifikasi kebutuhan belajar, permasalahan dan menentukan prioritas masalah, sumber-sumber atau potensi yang tersedia,. Hasil dari identifikasi digunakan sebagai dasar dalam menentukan tujuan pembelajaran.dan penetapan program kegiatan pembelajaran.
Partisipasi dalam pembelajaran adalah keterlibatan peserta didik dalam menciptakan iklim pembelajaran yang kondusif. Iklim belajar yang kondusif ditandai dengan 1) kedisiplinan peserta didik, 2) terjadi hubungan antar peserta didik dan antara peserta didik dengan pendidik yang akrab, terbuka, terarah, saling menghargai, saling membantu dan saling belajar, 3) Interaksi pembelajar yang sejajar. Kegiatan pembelajaran lebih ditekankan pada peran peserta didik (student centered). Peserta didik diberikan kesempatan secara luas dalam kegiatan pembelajaran, peran pendidik membantu peserta didik dalam melakukan kegiatan pembelajaran. Banyak pendekatan pembelajaran yang dapat diterapkan dalam menciptakan iklim pembelajaran kondusif, misalnya: pendekatan tematik, descoveriinkuiri, kontektual, cooperative learning, konstruktrukvistik, meaningfull learning, dsb. Adapun metode pembelajaran yang diterapkan, misalnya; metode diskusi, tanya jawab, problem solving, discovery-inkuiri, simulasi, brainstorming, role playing, games, siklus belajar berbasis pengalaman, demonstrasi, kooperatif, dan sebagainya. Partisipasi dalam evaluasi pembelajaran adalah keterlibatan peserta didik dalam menghimpun informasi mengenai pengelolaan pembelajaran dan perubahan yang dirasakan selama mengikuti proses pembelajaran. Dalam partisipasi evaluasi pembelajaran ini, pendidik memberikan kesempatan kepada peserta didik untuk 
memberikan penilaian pada seluruh komponen pembelajaran (refeksi pembelajaran) dan suasana diri (mood meter) dalam mengikuti pembelajaran. Langkah-langkah yang dilakukan pendidik dalam menerapkan strategi pembelajaran partisipatif adalah: 1) melakukan asesment kebutuhan belajar, merumuskan tujuan, mengidentifikasi hambatan, dan menetapkan prioritas yang akan digunakan untuk mengelola kegiatan pembelajaran. 2) Memilih tema/pokok bahasan dan/atau tugas yang harus dilakukan dalam pembelajaran dan menentuka indicator pencapaian tujuan pembelajaran. 3) Mengenai dan mengkaji karakteristik peserta didik sebagai bahan masukan dalam menyusun rencana pembelajaran 4) Mengidentifikasi isi/materi atau bahan pelajaran/rincian tugas pembelajaran 5) Merumuskan tujuan pembelajaran, 6) Merancang kegiatan pembelajaran, dengan memilih metode, media pembelajaran yang digunakan secara tepat dan pengelolaan waktu. 7) Memilih fasilitas pembelajaran dan sumber bahan yang mendukung proses pembelajaran. 8) Mempersiapkan sistem evaluasi proses dan hasil kegiatan pembelajaran. 9) Mempersiapkan tindak lanjut dari kegiatan pembelajaran yang dilakukan. Menurut Tom Nesbit, Linda Leach \& Griff Foley (2004) bahwa ada enam prinsip dalam praktek pembelajaran orang dewasa agar dapat diterapkan secara efektif, yaitu: 1) adanya partisipasi secara sukarela, 2) adanya perasaan respek secara timbal balik, 3) Adanya semangat berkolaborasi dan kooperasi, 4) adanya aksi dan refleksi, 5) tersedianya kesempatan refleksi kritis dan 6) adanya iklim pembelajaran yang kondusif untuk belajar secara mandiri. Prinsip tersebut sangat berkaitan dengan karakteristik orang dewasa yang telah memiliki konsep diri dan pengalaman yang cukup banyak. Konsep diri orang dewasa telah mandiri dan bergantung sepenuhnya kepada orang lain dalam menentukan pemecahan masalah. Pengalaman merupakan pembelajaran yang sangat berharga bagi orang dewasa. Setiap peserta memiliki pengalaman yang bervariasi, tingkat pendidikan, kematangan dan lingkungan yang berbeda pula. Untuk itu pembelajaran hendaknya memperhatikan hal-hal sebagai berikut: 1) peserta sebagai sumber belajar, oleh karena itu teknik pembelajaran yang diterapkan diorientasikan pada upaya penyerapan pengalaman mereka melalui; diskusi kelompok, curah pendapat, bermain peran, simulasi, curah pendapat, demonstrasi, focus broup discussion. 2) penekanan pada aplikasi praktis, pengetahuan baru, konsepkonsep, dan pengalaman baru dapat dijelaskan melalui pengalaman praktis yang pernah dialami peserta didik. Hasil dari pembelajaran dapat dimanfaatkan secara langsung dalam kehidupannya. 3) materi pembelajaran dirancang berdasarkan pengalaman dan kondisi peserta didik. Strategi pembelajaran dapat ditinjau dari ilmu, seni dan keterampilan yang digunakan 
pendidik dalam membantu (memotivasi, membimbing, membelajarkan dan memfasilitasi) peserta didik dalam belajar. Di samping itu strategi pembelajar dapat dimaknai sebagai prosedur pembelajaran dalam mengelola secara sistematis kegiatan pembelajaran dari beberapa komponen pembelajaran (materi pembelajaran, peserta didik, waktu, alat, bahan, metode pembelajaran, sistem evaluasi) dalam mencapai tujuan yang telah ditetapkan. Strategi pembelajaran orang dewasa (andragogi) merupakan prosedur yang dilakukan dalam membantu orang dewasa dalam belajar. Dalam belajar, orang dewasa telah memiliki konsep diri yang harus dihargai, memiliki pengalaman yang dapat dijadikan sumber belajar, orientasi belajar diarahkan pada upaya pemenuhan kebutuhan dan peningkatan peran dan status sosial dalam masyarakat.

Seperti telah disebutkan di atas bahwa dalam diri orang dewasa sebagai siswa yang sudah tumbuh kematangan konsep dirinya timbul kebutuhan psikologi yang mendalam yaitu keinginan dipandang dan diperlakukan orang lain sebagai pribadi utuh yang mengarahkan dirinya sendiri. Namun, tidak hanya orang dewasa tetapi juga pemuda atau remaja juga memiliki kebutuhan semacam itu. Sesuai teori Peaget (1959) mengenai perkembangan psikologi dari kurang lebih 12 tahun ke atas individu sudah dapat berfikir dalam bentuk dewasa yaitu dalam istilah dia sudah mencapai perkembangan pikir formal operation. 92
Dalam tingkatan perkembangan ini individu sudah dapat memecahkan segala persoalan secara logik, berfikir secara ilmiah, dapat memecahkan masalah-masalah verbal yang kompleks atau secara singkat sudah tercapai kematangan struktur kognitifnya. Dalam periode ini individu mulai mengembangkan pengertian akan diri (self) atau identitas (identitiy) yang dapat dikonsepsikan terpisah dari dunia luar di sekitarnya. Berbeda dengan anak-anak, di sini remaja (adolescence) tidak hanya dapat mengerti keadaan benda-benda di dekatnya tetapi juga kemungkinan keadaan bendabenda itu di duga. Dalam masalah nilai-nilai remaja mulai mempertanyakan dan membanding-bandingkan. Nilai-nilai yang diharapkan selalu dibandingkan dengan nilai yang aktual. Secara singkat dapat dikatakan remaja adalah tingkatan kehidupan dimana proses semacam itu terjadi, dan ini berjalan terus sampai mencapai kematangan. Dengan begitu jelaslah kiranya bahwa pemuda (tidak hanya orang dewasa) memiliki kemampuan memikirkan dirinya sendiri, dan menyadari bahwa terdapat keadaan yang bertentangan antara nilai-nilai yang dianut dan tingkah laku orang lain. Oleh karena itu, dapat dikatakan sejak pertengaham masa remaja individu mengembangkan apa yang dikatakan "pengertian diri" (sense of identity). Pembelajaran yang diberikan kepada orang dewasa dapat efektif (lebih cepat dan melekat pada ingatannya), bilamana pembimbing (pelatih, pengajar, 
penatar, instruktur, dan sejenisnya) tidak terlalu mendominasi kelompok kelas, mengurangi banyak bicara, namun mengupayakan agar individu orang dewasa itu mampu menemukan alternatif-alternatif untuk mengembangkan kepribadian mereka. Seorang pembimbing yang baik harus berupaya untuk banyak mendengarkan dan menerima gagasan seseorang, kemudian menilai dan menjawab pertanyaan yang diajukan mereka. Orang dewasa pada hakikatnya adalah makhluk yang kreatif bilamana seseorang mampu menggerakkan/menggali potensi yang ada dalam diri mereka. Dalam upaya ini, diperlukan keterampilan dan kiat khusus yang dapat digunakan dalam pembelajaran tersebut. Di samping itu, orang dewasa dapat dibelajarkan lebih aktif apabila mereka merasa ikut dilibatkan dalam aktivitas pembelajaran, terutama apabila mereka dilibatkan memberi sumbangan pikiran dan gagasan yang membuat mereka merasa berharga dan memiliki harga diri di depan sesama temannya. Artinya, orang dewasa akan belajar lebih baik apabila pendapat pribadinya dihormati, dan akan lebih senang kalau ia boleh sumbang saran pemikiran dan mengemukakan ide pikirannya, daripada pembimbing melulu menjejalkan teori dan gagasannya sendiri kepada mereka. Oleh karena sifat belajar bagi orang dewasa adalah bersifat subjektif dan unik, maka terlepas dari benar atau salahnya, segala pendapat, perasaan, pikiran, gagasan, teori, sistem nilainya perlu dihargai. Tidak menghargai (meremehkan dan menyampingkan) harga diri mereka, hanya akan mematikan gairah belajar orang dewasa. Namun demikian, pembelajaran orang dewasa perlu pula mendapatkan kepercayaan dari pembimbingnya, dan pada akhirnya mereka harus mempunyai kepercayaan pada dirinya sendiri. Tanpa kepercayaan diri tersebut, maka suasana belajar yang kondusif tak akan pernah terwujud. Orang dewasa memiliki sistem nilai yang berbeda, mempunyai pendapat dan pendirian yang berbeda. Dengan terciptanya suasana yang baik, mereka akan dapat mengemukakan isi hati dan isi pikirannya tanpa rasa takut dan cemas, walaupun mereka saling berbeda pendapat. Orang dewasa mestinya memiliki perasaan bahwa dalam suasana/ situasi belajar yang bagaimanapun, mereka boleh berbeda pendapat dan boleh berbuat salah tanpa dirinya terancam oleh sesuatu sanksi (dipermalukan, pemecatan, cemoohan, dan lain-lain). Keterbukaan seorang pembimbing sangat membantu bagi kemajuan orang dewasa dalam mengembangkan potensi pribadinya di dalam kelas, atau di tempat pelatihan. Sifat keterbukaan untuk mengungkapkan diri, dan terbuka untuk mendengarkan gagasan, akan berdampak baik bagi kesehatan psikologis, dan psikis mereka. Di samping itu, harus dihindari segala bentuk akibat yang membuat orang dewasa mendapat ejekan, hinaan, atau dipermalukan. Jalan terbaik hanyalah diciptakannya suasana keterbukaan dalam sega- 
la hal, sehingga berbagai alternatif kebebasan mengemukakan ide/gagasan dapat diciptakan. Dalam hal lainnya, tidak dapat dinafikkan bahwa orang dewasa belajar secara khas dan unik. Faktor tingkat kecerdasan, kepercayaan diri, dan perasaan yang terkendali harus diakui sebagai hak pribadi yang khas sehingga keputusan yang diambil tidak harus selalu sama dengan pribadi orang lain. Kebersamaan dalam kelompok tidak selalu harus sama dalam pribadi, sebab akan sangat membosankan kalau saja suasana yang seakan hanya mengakui satu kebenaran tanpa adanya kritik yang memperlihatkan perbedaan tersebut. Oleh sebab itu, latar belakang pendidikan, latar belakang kebudayaan, dan pengalaman masa lampau masing-masing individu dapat memberi warna yang berbeda pada setiap keputusan yang diambil.

Bagi orang dewasa, terciptanya suasana belajar yang kondusif merupakan suatu fasilitas yang mendorong mereka mau mencoba perilaku baru, berani tampil beda, dapat berlaku dengan sikap baru dan mau mencoba pengetahuan baru yang mereka peroleh. Walaupun sesuatu yang baru mengandung resiko terjadinya kesalahan, namun kesalahan, dan kekeliruan itu sendiri merupakan bagian yang wajar dari belajar. Pada akhirnya, orang dewasa ingin tahu apa arti dirinya dalam kelompok belajar itu. Bagi orang dewasa ada kecenderungan ingin mengetahui kekuatan dan kelemahan dirinya. Dengan demikian, diperlukan adanya evaluasi bersama oleh seluruh 94 anggota kelompok dirasakannya berharga untuk bahan renungan, di mana renungan itu dapat mengevaluasi dirinya dari orang lain yang persepsinya bisa saja memiliki perbedaan.

\section{METODE PENGABDIAN}

Pelatihan dilaksanakan pada bulan Mei 2016, selama 2 (dua) hari sabtu yaitu pada tanggal 7 dan 14 Mei 2016. dimulai pukul 10.00 pagi sampai dengan pukul 17.00 Wita. Tujuan pelatihan agar peserta memiliki pengetahuan tentang: (1) Sejarah dan Teori Belajar Orang Dewasa, (2) Asumsi-Asusmsi belajar orang dewasa dan (3) Penerapan teori belajar orang dewasa dalam proses pembelajaran. Tujuan pelatihan tersebut sekaligus menjadi materi pembelajaran pelatihan. Kegiatan pelatihan tersebut dilakukan dengan pentahapan sebagai berikut (1) Perencanaan, (2) Pelaksanaan dan (3) Evaluasi pelatihan. Kegiatan yang dilakukan pada tahap perencanaan antara lain tentang waktu dan tempat pelaksanaan, sumber belajar, kegiatan sasaran (pengelola dan tutor), metode pelatihan dan evaluasi. Kegiatan pada tahap pelaksanaan pelatihan yaitu melaksanakan pelatihan oleh panitia dan sumber belajar. Metode yang digunakan dalam bentuk ceramah, dikusi, curah pendapat dan demontrasi. Kegiatan tahap evaluasi pelatihan terfokus pada pelaksanaan keseluruhan kegiatan pelatihan. 


\section{HASIL DAN PEMBAHASAN}

Hasil

Melalui pelatihan tersebut warga belajar berhasil menguasai: (1) pengetahuan tentang Sejarah Teori Belajar Orang Dewasa, (2) asumsi-asumsi yang digunakan pada belajar orang dewasa dan kemampuan dan kemauan untuk menerapkan teori teori pembelajaran orang dewasa dalam proses belajar and berlatih di LPK.

\section{Pembahasan}

Pelatihan sebagai suatu proses pendidikan yang berlangsung di luar sekolah pada umumnya memiliki warga belajar atau peserta didik tergolong orang dewasa (usia > 25 tahun). Orang dewasa sebagai warga belajar memiliki karaktersitik khusus diantaranya menghendaki agar setiap kegiatan pembelajaran berorientasi pada pemecahan masalah yang dihadapi. Dengan begitu materi kegiatan pelatihan harus diawali dengan kajian terhadap apa, mengapa dan bagaimana kebutuhan belajar calon warga belajar. Karenanya, kegiatan pelatihan yang baik minimal memiliki tiga tahap yaitu tahap perencanaan, pelaksanaan dan evaluasi.

\section{KESIMPULAN DAN SARAN}

\section{Kesimpulan}

1. Pelaksanaan pelatihan ini para peserta, memiliki wawasan baru tentang Sejarah Teori Belajar Orang Dewasa.
2. Melalui pelaksanaan pelatihan ini para peserta memiliki pengetahuan, yang berhubungan dengan dengan asumsiasumsi yang digunakan pada belajar orang dewasa.

3. Peserta pelatihan memiliki kemampuan dan kemauan untuk menerapkan Strategi penerapan teori pembelajaran orang dewasa dalam kegiatan pembelajaran di LPK.

\section{Saran}

1. Agar para pendidik di LPK untuk terus meningkatkan wawasan tentang sejarah teori belajar orang dewasa.

2. Agar para pendidik dan pengelola pada berbagai LPK SD memiliki pengetahuan, sikap, keterampilan, kemampuan dan kemauan untuk melaksanakan dan menerapkan asumsi-asumsi yang melandasi bagaimana orang dewasa belajar.

3. Agar setiap pendidik dan pengelola pada ragam LPK menerapkan strategi belajar orang dewasa dalam proses pembelajaran dan pelatihan keterampilan.

\section{KEPUSTAKAAN}

Anonimus. 2005. “Undang-Undang Negera Republik Indonesia Nomor 14 Tahun 2005 tentang Guru dan Dosen". Citra Umbara. Bandung.

Anonimus. 2005. "Peraturan Pemerintah Nomor 29 Tahun 2005 tentang Standar Nasional Pendidikan". BP. Cipta-Jaya. Jakarta. 
Anonimus, 2003. Undang-Undang Nomor 20 Tahun 2003 Tentang Sistem Pendidikan Nasional beserta penjelasannya. FM. Fokus Media. Bandung.

Arif, Zainuddin. (1994). Andragogi. Bandung: Angkasa.

Asmin, Konsep dan Metode Pembelajaran Untuk Orang Dewasa (Andragogi),http://www. depdiknas.go.id/Jurnal/34/konsep_dan_ metode_pembelajaran.htm,Diakses tanggal 11 November 2006.

Knowles, Malcolm S. (1970). "The modern practicsof adult education, andragogy versus ". New York : Association Press.

Lunandi, A, G. (1987). Pendidikan orang dewasa. Jakarta: Gramedia.
Piaget, J. (1959). "The growth of logical thinking from childood fo adolescence. New York : Basic Books.

M. Thoyib. (2006). Memfasilitasi Pelatihan Partisipatif (Pengantar Pendidikan Orang Dewasa), http://depsos.go.id/modules.php?name =News\&file=print\&sid=209, diakses tanggal 11 November 2006.

Tamat, Tisnowati. (1984). Dari Pedagogik ke Andragogik. Jakarta: Pustaka Dian. http://www.

oocities.org/teknologipembelajaran/an dragogi.html. Diakses, 11 Pebruari. 2016 Pkl. 11,21

http://ayaadin.blogspot.com/2013/02/stan dar-dan-prinsip-

embelajaran.html.Download Jumat, 21 Maret 2014 